\title{
Bacterial Cast Measurement
}

National Cancer Institute

\section{Source}

National Cancer Institute. Bacterial Cast Measurement. NCI Thesaurus. Code C74762.

The determination of the amount of bacterial casts present in a urine sample. 